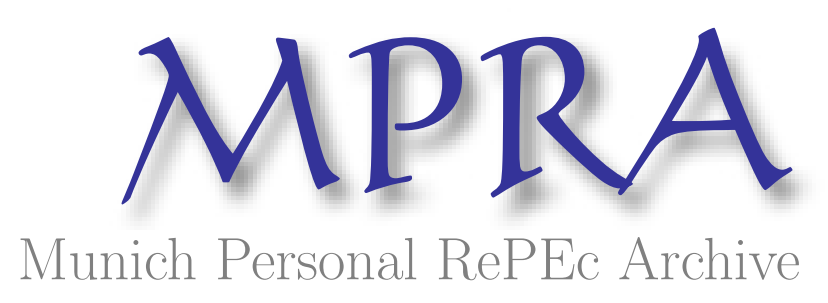

\title{
Basic education as a human right redux
}

Larry Willmore

International Institute for Applied Systems Analysis

26. July 2008

Online at http://mpra.ub.uni-muenchen.de/40478/

MPRA Paper No. 40478, posted 4. August 2012 17:28 UTC 


\title{
Basic Education as a Human Right Redux
}

Larry Willmore

International Institute for Applied Systems

Analysis (IIASA), 2361 Laxenburg, Austria

E-mail: willmore@iiasa.ac.at

Web: www.geocities.com/larrywillmore

Second Global International Studies Conference

University of Ljubljana, Slovenia

26 July 2008, SA03, 9:30 AM.

\begin{abstract}
The Universal Declaration of Human Rights promises free elementary education and free choice of schools to children and their parents. International fora emphasise the first right while neglecting the second. This essay examines arguments for limiting school choice and finds each of them to be unconvincing. It then describes three school systems: India, with free choice, but only for those who can afford to pay; Sweden, with taxpayer-funded free choice for everyone; and Finland, which allows parents almost no choice at all in basic education.
\end{abstract}

\section{Introduction}

Everyone has the right to education. Education shall be free, at least in the elementary and fundamental stages. Elementary education shall be compulsory. Article 26(i)

Parents have a prior right to choose the kind of education that shall be given to their children. Article 26(iiii)

Universal Declaration of Human Rights (1948)

The United Nations General Assembly in 1948 recognized basic education as a human right and called for primary education everywhere to be compulsory and free. Declaring something to be a right is not the same as achieving it, and progress was slow. Four decades later more than 100 million children lacked access to primary schooling, and millions more attended schools that failed to equip them with even minimal levels of literacy and numeracy. In 1990 delegates to the World Conference on Education for All in Jomtien, Thailand pledged to meet the goal of universal basic education by the year 2000. The number of children in school increased in the subsequent decade, but so did the number out of school, and the goal was not met. At the World Education Forum 2000 in Dakar, Senegal, delegates moved the target date to the year 2015. The General Assembly, in its Millennium Declaration of 8 September 2000, adopted this target and the date as one of its goals.

The General Assembly in 1948 also recognized as a human right the freedom of parents "to choose the kind of education that shall be given to their 
children". This right is violated, to a greater or lesser extent, in nearly every country on Earth, and progress has been slower toward the right to school choice than it has been toward the right to basic education. Nonetheless, delegates to Jomtien in 1990 , and Dakar in 2000 ignored freedom of choice, as did the General Assembly in its Millennium Declaration of September 2000. This is a pity because school choice is important, not only in its own right but also because it can promote universal education by making schools more attractive to parents and children.

This essay is about school choice, not privatisation. Meaningful choice is not possible without access to private schools. But privatisation alone does nothing to increase choice; it simply transforms a government monopoly into a private monopoly. The question addressed, then, is not why government finances schools, but rather why government finances only a subset of schools, typically those it owns and operates. For most goods and services, expanded consumer choice translates into greater welfare. What is different about schooling? An examination of the school systems of India, Sweden and Finland sheds light on this issue.

\section{Arguments against school choice}

Our first example is India, in part because it is a large country, home to 22\% of the world's population and $46 \%$ of its illiterates, but more importantly because it has a typical school system with limited choice that has been the object of a number of excellent studies, including Public Report on Basic Education in India (PROBE Team, 1999).

India, like most countries in the world today, limits free schooling largely to government schools, but permits choice for those who are willing and able to pay full tuition fees at a private school. How good are government schools in India compared to those that are privately run? The PROBE Team (1999, pp. 63-64) sought to answer this question by visiting, unannounced, all schools in 188 randomly selected villages in four, educationally backward northern states. These villages, with populations in the range of 300 to 300,000, contained 195 government schools and 41 private schools. ${ }^{1}$ In half of the government schools they found no teaching activity at all at the time of the visit. Moreover, this pattern of idleness "is not confined to a minority of irresponsible teachers-it has become a way of life in the profession". In contrast, they found a "high level of teaching activity in private schools, even makeshift ones where the work environment is no better than in government schools." The report stresses

\footnotetext{
${ }^{1}$ The PROBE Team (p. 103) acknowledges that they missed some private schools, especially the unrecognized schools that are not allowed to issue certificates. Results for a survey of Himachal Pradesh are reported separately in chapter 9 of the PROBE study. In that state, the team surveyed 48 randomly selected villages, which contained 48 government schools and-by their count -9 private schools. Because government schools were functioning relatively well in rural areas of Himachal Pradesh, very few private schools operated there, even though incomes are higher in Himachal Pradesh than in the other four surveyed states.
} 
"the key role of accountability in the schooling system. In a private school, the teachers are accountable to the manager (who can fire them), and, through him or her, to the parents (who can withdraw their children). In a government school, the chain of accountability is much weaker, as teachers have a permanent job with salaries and promotions unrelated to performance. This contrast is perceived with crystal clarity by the vast majority of parents."

The poor, of course, cannot afford high tuition fees. In Indian villages, however, fees at private schools are low, much lower than the cost to taxpayers of government schools, in large part because "private-school teachers ... receive very low salaries-often less than one-fifth of the salary of a government teacher with similar teaching responsibilities" (PROBE Team, 1999, p. 104). Because of these low tuition fees, "even among poor families and disadvantaged communities, one finds parents who make great sacrifices to send some or all of their children to private schools, so disillusioned are they with government schools" (PROBE Team, 1999, p. 103). Nonetheless, the very poor, realistically, face a choice of attending the government school or dropping out, and many opt for the latter. If tuition fees were reduced or eliminated at private schools, more parents would no doubt keep their children in school rather than allow them to drop out.

The authors of Public Report on Basic Education in India are sincere in their desire to make schools and teachers accountable to parents, yet they insist that this be accomplished through collective action, without providing public finance to private schools. This is not an easy task because "neglect of elementary education has been a persistent feature of public policy in most states since independence" (PROBE Team, 1999, p.131). It is, of course, possible for parents to make government schools accountable to their needs, as success in the states of Kerala (Drèze and Sen, 1995; Sen, 1997) and Himachal Pradesh (PROBE Team, 1999, pp. 115-127) demonstrates. In Himachal Pradesh, one of the success stories, it is

"the vigilance of parents, and their ability to keep the local teachers and administrators on their toes, that keeps the system going. The role of parental vigilance as an accountability mechanism takes a conspicuous form from time to time, for instance when a school threatens to break down. We heard several interesting stories of villagers resorting to spontaneous agitation (e.g., blocking the road or threatening to boycott the elections) to obtain a new school, or effect the transfer of negligent teachers " (PROBE Team, 1999, p. 124).

Clearly, though possible, it is difficult for parents to assert their rights through collective action. It is much easier to change schools than to change the school.

A simple and direct way to empower parents is for government to stand prepared to pay the tuition fees of any student at a competing, private school up to the amount it spends per student in a government school. The PROBE team (1999, pp. 105-106) rejects this option on grounds that private education 
has "serious limitations" compared to public education. Their arguments are not compelling, however, nor are they new. The alleged limitations of private education are:

1. Private teachers prepare students only to pass examinations, so they "have little reason to promote the personal development of the children ...or to impart a sense of values." Values are not defined, but the authors of this report presumably have in mind common values of civil society, which are necessary if modern democracy is to function smoothly.

2. Since "private schools often take advantage of the vulnerability of parents," government must protect children from poor choices that might otherwise be made by their parents.

3. "Private schooling remains out of reach of the vast majority of poor parents, who cannot afford the fees and other expenses." As a result, "children enrolled in private schools come mainly from better-off families." This, presumably, is objectionable only on egalitarian grounds. The PROBE team makes this argument explicit in what they list as a fourth danger of private education: it "may lead to a very divisive pattern of schooling opportunities, with better-off parents sending their children to private schools while poorer parents are left to cope with non-functional government schools."

We examine each of these arguments in turn.

\section{Impart civil values (civic education)}

The need to transmit common values to children is the oldest argument for state control of education. It is for this reason that Aristotle, like his teacher, Plato, disliked the schools of his day, which were private and independent of government. In $350 \mathrm{BCE}$, Aristotle drafted this forward-looking piece of advice:

"[I]t is manifest that education should be one and the same for all, and that it should be public, and not private-not as at present, when every one looks after his own children separately, and gives them separate instruction of the sort which he thinks best; the training in things which are of common interest should be the same for all. Neither must we suppose that any one of the citizens belongs to himself, for they all belong to the state...." (Politics, Book Eight, Part I)

The pronoun 'himself' is deliberate; women were not citizens in ancient Athens, so were thought to have no need of education. This applied as well to slaves and other non-citizens. 
Today, much has changed: state schools dominate, and they educate girls as well as boys. But some things remain the same: champions of government schools continue to invoke the 'civic education' argument in their defence (see Kremer and Sarychev, 2000; Macedo, 2000; Gradstein and Justman, 2002; Pritchett, 2003).

There are three problems with this view. First, the 'civic education' argument should call not only for government schools, but also for compulsory attendance at government schools to ensure that all students are taught the same common values. In practice, attendance at government schools is rarely compulsory. Most governments, including that of India, allow parents to pay private tuition at a school of their choice, and some allow home schooling as well. Second, it is inconsistent with decentralised systems of education in nation-states such as India, Canada and the United States, where the school curriculum is far from uniform across states, provinces or municipalities. Third, and most importantly, it assumes that governments can control the curriculum if they own the schools. Large bureaucracies have a life of their own; state school teachers, in particular, are prone to form powerful unions and are not easy to control. Paradoxically, it may be easier for government to control private schools, by threatening to revoke licences if specified standards are not met (see Gintis, 1995; Shleifer, 1998).

Apart from the question of how best to transmit uniform values to pupils, there remains the much broader issue of whether such a goal is desirable. Writers in the classical liberal tradition celebrate diversity, and argue that uniformity of thought, in religion, politics or any area of study, ought to be avoided at all costs. John Stuart Mill, in a famous passage from his essay On Liberty (1909 [1859], chapter V), expressed this view most eloquently:

"A general State education is a mere contrivance for moulding people to be exactly like one another: and as the mould in which it casts them is that which pleases the predominant power in the government, whether this be a monarch, a priesthood, an aristocracy, or the majority of the existing generation, in proportion as it is efficient and successful, it establishes a despotism over the mind, leading by natural tendency to one over the body. An education established and controlled by the State, should only exist, if it exist at all, as one among many competing experiments, carried on for the purpose of example and stimulus, to keep the others up to a certain standard of excellence."

Sixteen years later, Karl Marx (1875) took an even stronger stand against government schools:

"Elementary education by the state' is altogether objectionable. Defining by a general law the expenditures on the elementary schools, the qualifications of the teaching staff, the branches of instruction, etc., and ... supervising the fulfillment of these legal specifications by state inspectors, is a very different thing from 
appointing the state as the educator of the people! Government and church should rather be equally excluded from any influence on the school."

On the subject of school choice, the Universal Declaration of Human Rights is a very liberal document. The Declaration states that parents have a right to choose the education of their children and does not qualify this right in any way. Parental choice is not restricted to schools operated by the state, and parents are not asked to give up their right to free education in order to exercise their right to choice of education. Preferences of individuals are respected even when they conflict with collective values of the nation-state.

\section{Protect children}

A second argument against school choice asserts that many or most parents are not capable of choosing wisely the education that is best for their own children, so government ought to make this choice for them. This is different from the 'civic education' argument because, under this criterion, government intervenes in the interest of individuals, not in the interest of society as a whole. In effect, the state behaves as a loving parent to all children, so this can be described as a paternalistic argument for government schools.

The argument dates from the 16th century Protestant Reformation, which set as its goal universal, compulsory education for everyone, girls as well as boys. Protestants were concerned that the adult population of their day was overwhelmingly illiterate and, presumably, too ignorant to make correct choices for the Christian education of their children. Martin Luther (1962, p. 355 ), as leader of the Reformation, expressed this sentiment with great clarity in a letter directed to councilmen of all the cities of Germany in the year 1524:

"[T]he great majority of parents unfortunately are wholly unfitted for this task [of educating the young]. They do not know how children should be brought up and taught, for they themselves have learned nothing but how to care for their bellies. It takes extraordinary people to bring children up right and teach them well."

According to Luther (1962 [1524], p. 370), government officials should be entrusted to select these "extraordinary people" to staff schools where children can study "for one or two hours during the day, and spend the remainder of the time working at home, learning a trade, or doing whatever is expected of them".

Nearly five centuries after Luther wrote these words, precisely the same assertion of parental ignorance continues to be invoked to justify government control of schools, not only in India, but also in developed countries that have attained near universal adult literacy. (For a clear statement of this view, see the remarks of Professor John F. Covaleskie in Glass, 1994; see also Dwyer, 1998 and Barry, 2001.) 
No doubt some parents are unable, or unwilling, to make an informed choice of school for their children. Does this justify denying all parents their right to school choice? In other aspects of child welfare, such as food, shelter and clothing, parents are given the benefit of the doubt. The state assumes custody only of those children whose parents are unable or unwilling to provide for them. The state does not assume the task of selecting food, shelter and clothing for all children.

In any case, it is possible to address paternalistic concerns of society with measures short of denying school choice to all parents. Government can insist on minimum standards before licensing a school, eliminating the possibility that a parent makes a truly bad selection. It can punish schools that mislead or misinform parents of prospective students, publicise the results for each school of standard examinations of its students, and prohibit spending of public money for purposes unrelated to education. It can specify a core curriculum for all schools. Regulation has its cost, however, which takes the form of restricted choice. The heavy hand of regulation can eliminate choice just as effectively as refusal to finance private schooling.

\section{Promote equality}

The idea of promoting equality of opportunity through education is based on the following argument. Markets are inevitably inequitable because they distribute goods and services in a very unequal fashion. To ensure equality of access to secondary and higher education, all children should receive the same basic education. This can be guaranteed only with government schools. If people are given the freedom to choose among competing schools, they will sort themselves by social class, ethnic group or level of ability, thereby harming those who end up in schools filled with students of low social origin and limited intellectual talent. In the words of one opponent of school choice, "once we have isolated most low income children 'in their own schools' it will be difficult to sustain the significantly higher-than-average expenditures such children need to receive a quality education. This, in turn, means that all children in government schools that serve low-income students will have a lower quality education than they now have" (Hawley, 1995).

Albert Hirschman, in his influential book Exit, Voice and Loyalty, added a twist to this argument. In competitive markets, customers are free to 'exit' a service by switching to another supplier. The alternative to 'exit' is 'voice', expression of dissatisfaction directly to management or through general protest. These two reactions of exit and voice, Hirschman (1970, p. 47) reasoned, do not work well together because "those customers who care most about the quality of the product and who, therefore, are those who would be the most active, reliable, and creative agents of voice are for that very reason also those who are apparently likely to exit first in the case of deterioration." In the case of public schools, it is best to deny articulate complainers the right of exit: a 'tight monopoly' is preferable to a system that allows schools to compete for students. In sum, government schools will improve if attendance is made compulsory; they will deteriorate if government facilitates the 'exit' of unhappy parents. 
The 'equality of opportunity' argument is well intentioned but misguided, for it is based on a false premise. Government schools are not synonymous with equality of opportunity. Families sort themselves geographically by social class and by ethnic group when they choose their place of residence. Parents prefer to send children, especially young children, to a school near their place of residence, so some schools end up with disproportionate numbers of deprived children whereas others receive disproportionate numbers of privileged children.

Governments can reverse the effects of geographic sorting by transporting children to distant schools, thus obtaining, across schools, greater uniformity in the social class and ethnic origin of students. This is disliked by parents, especially parents of small children. An alternative way to promote equality is to ensure that all schools, regardless of the ethnic or social composition of the student body, offer the same standard of education. This requires directing a larger share of resources to schools that enrol large numbers of deprived children. This is also difficult, for such measures can be resisted by competent teachers, who resist transfers to difficult schools, or thwarted by parents who contract private, supplemental tutoring. Another tactic used by articulate and educated parents is to stay in the state system, but capture the schools for their own interests, which may conflict with interests of the poor and the ethnic minorities. One way this happens is with the introduction of 'streaming', the separation of students by ability, which results in their separation by social strata as well. More resources can then be channelled to the 'high performing' stream of students, at the expense of other students in the school.

Government schools, then, often fail to provide children with equality of opportunity. Markets, on the other hand, can be beneficial for the poor because markets are inequitable only if there is an inequitable distribution of purchasing power. So long as there is government finance of education, the market for education can be made as equitable as one likes. One proposal is to issue each child a voucher of the same value, to be used for payment of tuition fees at any state or private school (Gintis, 1995); for an alternative proposal, see Reich (2000). Exceptions could be made for children with learning disabilities or special needs, who would be eligible for a larger voucher. To keep this system egalitarian, it is important to prevent schools from charging fees in addition to the voucher. Otherwise, political pressure might lead to a reduction in the size of the voucher, thus segregating the poor in substandard schools while the middle-class and wealthy add to their vouchers at better schools.

Voucher schemes, then, are not inherently egalitarian or otherwise: it depends on their design. From an egalitarian perspective, the worst possible scheme is one that exempts government schools from the voucher system, and provides partial vouchers, insufficient to cover full tuition, to students who transfer to private schools. These vouchers are worthless unless parents supplement them with money of their own. The consequences of such a scheme would be a flight of children of middle- and upper-class parents to private schools, leaving the poor without any meaningful choice. This happens even without vouchers, but this type of voucher scheme accelerates the 
process. Vouchers result in greater inequality only because the poor lack effective purchasing power.

To sum up, those who have the interests of the disadvantaged at heart should not oppose school choice. Rather, they should work to design systems of education and finance that favour the poor, the inarticulate and the underprivileged, in contrast to current systems that so often trap children in failing schools and allow meaningful choice only for the wealthy, the articulate and the privileged.

\section{Recent developments in India}

The PROBE Team in 1996 sampled rural schools in four educationally backward states of India-Bihar, Madhya Pradesh, Rajasthan and Uttar Pradeshwhere they found little teaching activity and very poor facilities. Absenteeism was widespread. For example, "in one-third of all the schools covered by the PROBE survey, the headmaster was absent at the time of the investigators' visit" (p. 46). And, as already noted, in half the sample schools there was no teaching activity at all at the time of the visit. In addition, the investigators found 59 percent of the schools with no water supply, 89 percent without a functioning toilet, 52 percent without a playground, 77 percent without a library and 26 percent without a blackboard in every classroom (PROBE Team, p. 42).

There is no evidence that teaching quality has improved in subsequent years. If anything, it may have become worse. Kremer et al. (2005) made three unannounced visits to each of 3700 primary schools, a nationally representtative sample drawn from all states of India. They found a quarter of the teachers were absent from school on the days of the visit. Of those present, only 45 percent were actually engaged in teaching. Private school teachers' absenteeism was 8 percentage points lower than government school teachers in the same village. This may well reflect a greater risk of being fired for absenteeism in a private school. Only one head teacher in the nearly 3000 government schools recalled ever dismissing a teacher for repeated absence or tardiness, whereas head teachers in 35 of the 600 private schools reported such a dismissal. Unfortunately, however, these public/private comparisons are marred by the fact that private schools were sampled only in rural villages, whereas government schools were drawn from both rural villages and urban areas. It is likely that standards for private schools are higher in urban areas, where there is more competition.

School infrastructure, in contrast to teaching, has definitely improved since the PROBE survey of 1996, although much remains to be done. The ASER 2007 survey of rural schooling (Pratham, 2008, p. 49) found that 74 percent of sampled primary schools had water (up from 69 percent in 2005 and 41 percent in the PROBE survey) and 59 percent had a functioning toilet (up from 48 percent in 2005 and 11 percent in the PROBE survey). Remarkably, 93 percent of schools were serving students a midday meal on the day of the visit (up from 71 percent in 2005). This represents a huge change from 1996. School meals were launched nation-wide in August of 1995, 
but not one of the schools visited by the PROBE Team (1999, pp. 95-97) in September-December 1996 had introduced school meals.

The PROBE Team (1999, p. 102) found widespread private schooling in rural villages, even though this was "often thought to be confined to urban areas". Moreover, private schools were most common in villages where government schools were most dysfunctional. Private schooling, then, seems to be driven more by poor quality of government schools than by level of income. Among sample households in the four PROBE states, 18\% of schoolgoing children were enrolled in private schools. This statistic varied widely, however, registering 36 percent in Uttar Pradesh and 5 to 11 percent in the other three states. Moreover, parents obviously were making sacrifices in addition to tuition expenses to send their children to private schools, as evidenced by the fact that half of the private school children attended a school outside there own village (compared to 11 percent of government school children).

In India, private schools' share of enrolment would seem to be a good (inverse) summary measure of the quality of government schooling. By this measure, school quality has fallen in rural India over the past decade and a half. Between 1993 and 2007, the proportion of primary students in private schools increased from 10.3 to 18.0 percent, a near doubling. For middle school, private schooling nearly tripled, from 7.9 to 23.0 percent, over the same period. (See table 1.) These estimates are based on household surveys, so include both recognized and unrecognized schools. Official statistics are based solely on recognized schools-those with a right to confer degrees-and show much less private schooling in India.

\section{Table 1: Rural India, private schools' share of enrolment in basic education, 1993-2007 (percent)}

$\begin{array}{lcc}\text { Year } & \text { Primary School } & \text { Middle School } \\ 1993 & 10.1 & 7.9 \\ 2005 & 16.2 & 19.5 \\ 2006 & 19.5 & 20.3 \\ 2007 & 18.0 & 23.0\end{array}$

Note: All estimates are based on household survey data, and include both recognized and unrecognized private schools. Official statistics include only recognized schools, so show a much lower private share of enrolment. Sources: Kingdon (2007, p. 184), ASER 2005 (Pratham, 2006, p. 16), and ASER 2007 (Pratham, 2008, p. 43).

The PROBE Team also visited schools in a fifth state-Himachal Pradesh-where the quality of teaching, though not the physical infrastructure, was far superior to that in the four 'educationally backward' PROBE states. The survey findings for this state are reported in a separate chapter. The PROBE Team had nothing but praise for the "schooling revolution" in Himachal Pradesh. This success, they note, is the result of a 
commitment of the state government to education as well as the previouslymentioned parental vigilance and collective action. Himachal Pradesh spends (or spent) about twice as much per-capita on education as the rest of India, and the pupil-teacher ratio in sample schools was 27, approximately half the ratio of 50 observed in the four PROBE states. Numbers of teachers on the payroll mean nothing, of course, if they are absent or do not teach. "The problem of teacher inertia, so devastating in other states, is not entirely absent in Himachal Pradesh, but it is much less widespread" (p. 120). Precise figures are not reported.

One result of this success, according to the PROBE Team (1999, p. 120) is "the virtual absence of private schools in rural areas of Himachal Pradesh. This vacuum is not due to the absence of purchasing power among parents .... Rather, it fits in a general pattern ...: private schools are most common in areas where government schools do not function. Conversely, if government schools function well, there may be little scope for private schools, as seems to be the case in rural Himachal Pradesh". The PROBE Team never reports precisely what percent of enrolment was in private schools in Himachal Pradesh, but in a methodological appendix note (p. 144) that parents in the 48 sample villages of that state had access to 48 government schools but only 6 private schools.

Since Himachal Pradesh was an outlier with excellent performance in 1996, it is interesting to see how well the state has done in recent years, compared to the four 'educationally backward' PROBE states. Student enrolment in private schools, we have seen, is an excellent summary measure of the quality of government schools in India. The poorer the quality of a government school, the more attractive is a private alternative. Table 2 reports three years of private schooling numbers for rural areas of Himachal Pradesh, the four PROBE states, and the all India average. In 2005 private schooling was less common in Himachal Pradesh than in any of the four PROBE states. In the subsequent two years, private schooling expanded everywhere, but especially in Himachal Pradesh. By 2007, 22.5 percent of the state's students were enrolled in private schools. This figure is higher than that for India as a whole, and higher than two of the four PROBE states. The inescapable conclusion is that the quality of government schools must have fallen sharply-at least quality as perceived by parents of school-age children.

Another striking statistic of table 2 is the low and declining importance of private schools in rural Bihar state. Is this indicative of a "schooling revolution" similar to that of Himachal Pradesh? Bihar is not a wealthy state, nor is it known for excellence in teaching. What seems to be happening is that Bihar parents are enrolling their children in part-time private tuition classes rather than full-time private schools (see table 3). One can only speculate why after-school private tuition is so popular in Bihar, but with 50 percent of government school students enrolled in these courses, it may well account for the low demand for spaces in full-time private schools. 
Table 2: Rural India, private schools' share of enrolment in Himachal Pradesh and the PROBE states, 2005-2007 11

\begin{tabular}{|c|c|c|c|}
\hline \multirow[t]{2}{*}{ State } & \multicolumn{3}{|c|}{ \% (aged 6-14) in private school } \\
\hline & 2005 & 2006 & 2007 \\
\hline Himachal Pradesh & 7.2 & $15 \cdot 0$ & 22.5 \\
\hline Bihar & 11.0 & 12.7 & 7.9 \\
\hline Madhya Pradesh & 8.7 & 11.7 & 13.5 \\
\hline Rajasthan & $25 \cdot 3$ & 28.3 & 28.6 \\
\hline Uttar Pradesh & 30.0 & 32.5 & 30.3 \\
\hline All India & 17.4 & 20.2 & 20.1 \\
\hline
\end{tabular}

Note: Estimates are based on household survey data, and include both recognized and unrecognized private schools. Basic education covers children aged 6-10 years (primary school) and 11-14 years (middle school). The original source reports share of children in private schools; the calculations above are the private schools' share of school going children. In all of rural India in $2005,16.3 \%$ of children attended private schools and $6.5 \%$ were not in school, so the percentage of students enrolled in private schools was 16.3(1-065)=17.4. Source: ASER 2006 (Pratham, 2007, p. 36), and ASER 2007 (Pratham, 2008, p. 47).

Table 3: Rural India, \% of government school children attending private tuition classes in Himachal Pradesh and the PROBE states, 2007

$\begin{array}{lcc}\text { State } & \text { Primary School } & \text { Middle School } \\ \text { Himachal Pradesh } & 3.0 & 6.2 \\ \text { Bihar } & 35.1 & 50.2 \\ \text { Madhya Pradesh } & 5.3 & 9.4 \\ \text { Rajasthan } & 2.5 & 6.2 \\ \text { Uttar Pradesh } & 5.0 & 9.3 \\ \text { All India } & 18.3 & 24.6\end{array}$

Note: Primary school is the average for years 1 to 5 ; middle school is the average for years 6 to 8 .

Source: ASER 2007 (Pratham, 2008, pp. 45, 61, 87, 93, 111, 139).

\section{Freedom of choice in Sweden}

Caroline Hoxby (2006), a Harvard economist who specializes in education, lists three elements that she believes are crucial if school choice is to result in improved school quality. These are:

1. supply flexibility;

2. money that follows students;

3. independent management of schools. 
I agree that all three are necessary if quality is to improve, but I would add two additional elements to increase the odds that everyone benefits from choice. These are:

4. schools do not choose students; and

5. no school fees.

By supply flexibility, Hoxby means that schools must be free to open, to expand, and to contract or close if they fail to attract students. The second essential element is that schools must lose some of its public financing when they lose a student, and the money that follows the student must be approximately equal to the schooling cost for that student. Unless money follows students there can be no supply flexibility, so the first element depends very much on the second. The third essential element is freedom to innovate, to hire (and fire) staff and to compete for students. If all schools are exactly alike, there is no meaningful choice.

Even though parents choose schools, schools should not be allowed to choose students. If a school has more applicants than spaces, selection should be based length of time in the queue or a lottery once priority has been given to applicants with siblings already enrolled in the school. This is the fourth element, which is essential for anyone who believes strongly in the ideal of equal access to basic education. Hoxby (2006, p. 29) disagrees. She argues "first, it is a mistake to eliminate all forms of selection into schools because there is a cost of eliminating variety; and second, the ability to select students can convey competitive advantages to a school ...." It is true that allowing schools to select students will increase the differences between schools. Faithbased schools, for example, could restrict admission to those of the faith, and elite schools catering to students with high intelligence and scholastic aptitude could reject applicants of low intelligence and aptitude. But this is not the type of school variety envisaged by those who seek a more egalitarian society. In any case, restricting access to basic education seems contrary to the Universal Declaration of Human Rights. Hoxby's points are appropriate for higher education, not basic education. In fact, I would be uncomfortable if medical schools, for example, failed to discriminate against students of low intelligence and aptitude.

The fifth essential element is prohibition of school fees, which discourage applications from parents with low incomes. Hoxby disagrees, although she concedes "top-up fees seem dangerous. They could be used by schools as a method of enforcing income segregation or, perhaps more worrisome, they could lead to the development of a two-tier education system under which the government per-student subsidy provides an inadequate education and affluent parents reveal this by all choosing to top up the subsidy substantially" (p. 25). Her solution is "allow schools to ask parents to top up if the school practises need-blind admission and gives need-based scholarships that eliminate top-up fees for poorer families" (p. 25). With such a system, students would be segregated by ability rather than income. The top up to finance higher-than-average school costs would be paid only by the better-off parents of students in each elite school. Such a top up is in reality a tax on affluent parents that increases with schooling costs and with the number of 
scholarship students. This makes sense for elite universities like Harvard, but not for basic schooling, which should be egalitarian rather than elitist.

Sweden in 1992 embarked on a radical educational reform that satisfies all five of the essential elements for school choice listed above. This reform followed decentralization of the educational system in 1990, when authority to run primary and secondary schools was transferred to the municipalities.

Prior to 1992, Sweden's school system allowed for little choice. Government assigned pupils to their closest school, and parents had little to say in the matter, short of moving to a different neighbourhood. Very few private schools existed; most were faith-based and accounted for less than one percent of students in compulsory schooling, which in Sweden is nine years starting at age 7 .

In 1992 everything changed. Anyone can now open a school, and municipalities are required to finance it on the same per-pupil terms as a government school. Regulations exist, but are mild. All schools must follow the national curriculum, and private schools must be approved by the National Agency for Education to receive funding. Few private school applications are rejected. The views of municipalities that fear competition are taken into account, but municipalities have no veto and are obligated to finance a private school once its establishment has been approved. Power for the most part has been transferred from government to parents, who by their choice of schools determine the allocation of government finance. The only limitation on parental choice is that municipal schools must admit all applicants who reside in the municipality. Only if there are additional spaces available can municipal schools accept applications of non-residents. Other than this restriction, and preferences for applicants with siblings already enrolled, schools cannot discriminate in any way. There are no religious requirements or entrance exams. If applicants exceed vacant spaces for a school, those first in the queue are the first to be admitted. Education is financed in part by municipal taxes, so per pupil expenditure does vary by municipality. But the grant per pupil does not vary by school and no school is allowed to charge top up fees regardless of the size of the municipal grant.

There are no restrictions on ownership of private schools. Schools can be and are run by religious groups (Christian, Jewish, Muslim), teachers' cooperatives, parents' co-operatives or for-profit corporations. If a registered school attracts and retains students, it receives funding from the students' respective municipalities. Sweden has created a market for schooling, but it is a very egalitarian market because there is no price competition and each consumer has the same access to schools. Precisely because Sweden does not allow private schools to charge fees or select students, its system has attracted criticism from libertarian groups such as the Fraser Institute (1999).

By no means all Swedish parents have deserted government schools, but the private share of enrolment has increased, and came to exceed 10 percent in 2008. Surprisingly few of the new private schools are faith-based, but many are run for profit, some as chains of schools. The largest chain, Kunskapsskolan ("Knowledge Schools"), runs 30 schools with 700 employees 
and nearly 10,000 students. Its schools are very high-tech and rely on the Kunskapsporten ("Knowledge Portal"), a website that contains the entire syllabus, allows each student to work at his or her own level, and provides parents with a logbook that records their child's weekly progress. Teachers are monitored as well, and the most successful are given bonuses for good performance. The Economist compares Kunskapsskolan's management style to that of IKEA, the Swedish furniture company, which standardizes its products and gets customers involved in final assembly. (See Anonymous, 2008.)

Three econometric studies have examined the effect of introduction of school choice on the quality of education in Sweden: Ahlin (2003), Sandström, and Bergström (2005) and Böhlmark and Lindahl (2007). All three studies exploit the fact that private schooling varies by municipality, and all find that everyone gains from competition-pupils who remain in government schools as well as those who choose a private option. The reason this happens is that government schools, faced with competition from private schools, must improve their performance or lose pupils and funding. The collective gains for all parents living in a municipality are, in fact, greater than the individual gains of those who choose private schooling. Böhlmark and Lindahl (2007), for example, calculate that a 10 percentage point increase in private school share increases average grades overall by nearly one percentile point, but the individual gain from attending private school rather than government school is only one-tenth of a percentile point. Because gains are so disperse, all social and economic groups appear to benefit from introduction of choice. Even classroom teachers prefer the new system.

These three initial empirical studies are excellent, but do have some shortcomings. First, although school choice in Sweden applies, with some restrictions, equally to choice of government school, none of the studies take this into account. If government schools are competing with each other, and not just with private schools, the full effect of school choice on quality of schooling might be greater than measured in these studies. Second, expenditure per pupil is higher in municipalities with a higher private share, and this is taken by Böhlmark and Lindahl (2007, p. 39) as "evidence of a positive effect of private schooling on school costs". An alternative, more plausible explanation is that the incentive to open private schools is greater in municipalities with higher per pupil expenditure (Björklund et al., 2005, pp. 110-111).

\section{Lack of choice in Finland}

Finland attracts more international attention than Sweden, and for a different reason. After years of lacklustre, average performance in international examinations, Finland's students came to perform at or near the top in PISA, the Programme for International Student Assessment that the OECD in the year 2000 began to administer to fifteen-year old students every three years. In 2006, the year of the latest PISA exam, Finland ranked first on the science scale, and second in reading and mathematical performance. 
Everyone wants to know, in the words of a Wall Street Journal article, "What makes Finnish kids so smart?" (Gamerman, 2008). The roots of the country's success lie in two reforms implemented in the 1970s. The Comprehensive School Reform (1972-1975) extended compulsory schooling from eight to nine years and replaced the dual-track vocational and grammar (university preparatory) schools with mixed-ability comprehensive schools. The Teacher Education Reform (1973-1979) raised the requirements for primary school teachers from a three-year certificate from a teachers' training college to a five-year Master's degree from a university. Comprehensive schools give all Finnish children from age seven access to the same basic education, instead of sorting them immediately into academic and nonacademic streams. High academic standards transformed teaching into a high-status profession that attracts many of the Finland's brightest secondary school graduates (Simola, 2005, pp. 458-459; Sahlberg, 2007, pp. 154-155).

These early reforms, though important, by themselves cannot account for Finland's transition in education from an average performer during the 1980 s and 1990 s to a star international performer beginning in 2000. The key element to explain this seems to be development of what Sahlberg (2007, pp. 156-157) refers to as a "culture of trust". Finnish education was highly centralized before the reforms of the 1970s, and remained so until 1985 when there was a gradual shift toward trusting schools in general and classroom teachers in particular. By the early 1990s Finnish teachers had obtained freedom that public school teachers in many other countries (though not India!) might envy. "The school inspectorate, a detailed national curriculum, officially approved teaching materials, weekly timetables based on subjects taught and a class diary in which the teacher had to record what was taught each hour-all these traditional mechanisms were abandoned" (Simola, 2005, pp. 464-465). The system works well because teachers are exceptionally well trained and "parents trust teachers as professionals who know what is best for their children" (Sahlberg, 2007, p. 155). Ironically for a nation that performs well in international exams, Finland has never experimented with standardized tests at the compulsory school level.

School choice in Finland is extremely limited, almost non-existent. Each child is assigned to the closest public comprehensive school. Plato and Aristotle would approve of the uniformity of this system; John Stuart Mill and Karl Marx would not. Private schools are given state funding comparable to a municipal school of the same size, must admit applicants on the same basis as municipal schools, and cannot charge fees. This sounds similar to the system in effect in Sweden, but there is one big difference. Establishment or expansion of a private school requires a political decision. This is rarely given, so few private schools exist, most of them faith-based, and they are not allowed to expand.

The Finnish classroom is very different from a typical Swedish classroom. It is decidedly low-tech. There are no computers, overhead projectors instead of PowerPoint, and chalkboards instead of whiteboards (Gamerman, 2008). Teachers are professional but their teaching methods are very conservative, authoritarian and distant. Hannu Simola (2005, p. 463), professor of education at the University of Helsinki, discovered in an interview 
study of Danish, Finnish, Swedish and Norwegian teachers that "Finnish teachers differ from their Nordic colleagues in their relations with pupils and their families. While other Nordic teachers almost unanimously emphasized intimate, personal and confidential relations, Finnish teachers spoke to their pupils mostly as adult models and keepers of order and safety in the classroom. Rather than encouraging intimacy, some experienced Finnish teachers emphasized how important it was to keep a certain professional distance from their pupils and their homes and problems."

Finnish comprehensive schools are very egalitarian. There are no special classes for gifted students, nor is there streaming by ability. All students stay together in the same class, and bright students are expected to tutor backward students to bring them up to par. A special educational system for 'difficult' pupils-approximately a quarter of the cohort in recent yearsprovides extra services for lagging students to bring them up to the level of regular class. This special education, in the milieu of an exceptionally homogeneous Finnish population, has "the effect of unifying and harmonizing the groups taught by the classroom teacher" (Simola, 2005, p. 465).

Because of its egalitarian system-essentially the same basic school for everyone-Finland performs well in international comparisons not only in the level of student performance, but also in the variance of student performance across schools. For the science scale of PISA 2006, Finland not only ranked first of all participating countries, it also had the smallest variance between schools. (See figure 1.) The within-school variance for Finland, in contrast, was quite high-well above the average for the OECD. Each Finnish school, in other words, contains a heterogeneous mixture of students of varying ability, but the schools themselves are extremely homogeneous in terms of educational outcomes. This result is all the more remarkable when we recall that Finland, unlike other countries, has no streaming within its schools. Finnish classrooms, like its schools, are a mix of diverse students, but very homogeneous in terms of outcomes.

Finland has been very successful in attaining the twin goals of equity and efficiency in basic education. This success has come at a price, though, namely flagrant violation of a basic human right, the right of all parents "to choose the kind of education that shall be given to their children". The vast majority of Finnish parents, it is true, are satisfied with the basic education their children receive. But human rights are individual rights, not collective rights. Human rights exist to protect individuals and minorities from the tyranny of dictators and from the tyranny of majorities. Violation of any human right, then, should not be taken lightly. Available evidence is rather dated, but a 1995 survey of parents' attitudes toward comprehensive school showed that while $86 \%$ of respondents were satisfied with the teaching, only $48 \%$ were satisfied with treatment of a student's individuality, and $28 \%$ expressed dissatisfaction on this account (Simola, 2005, 458). A significant minority of Finnish parents is concerned with the absence of special classes or activities for gifted students and with what they perceive to be excessive homogenization of basic education. 
Figure 1: Variance in student performance within schools and between schools on the science scale (PISA 2006)

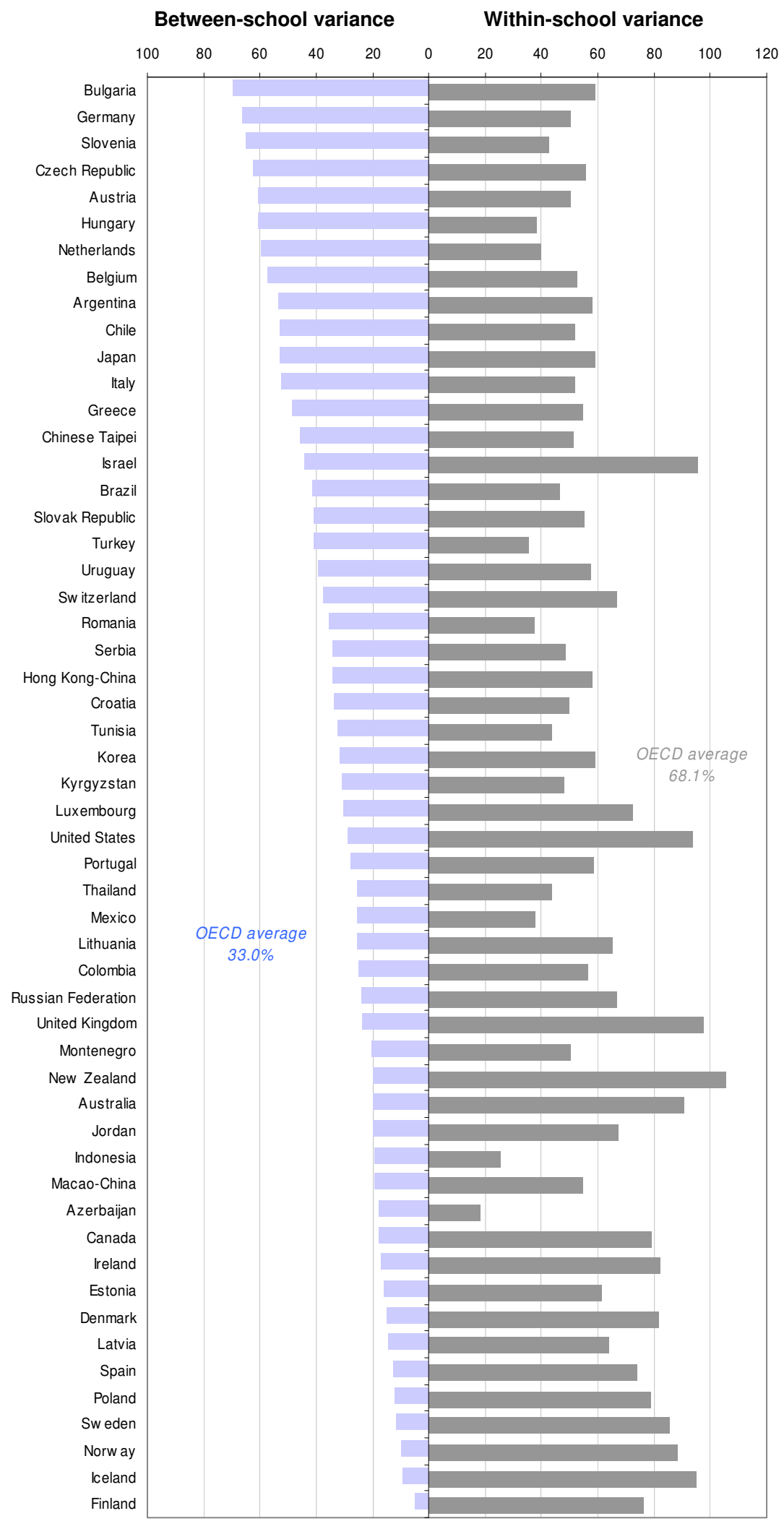

Source: PISA 2006 (OECD, 2007), vol. 1, figure 4.1, p. 171. 
Despite Finland's high standing in the world of education today, not everyone is optimistic about the future of schooling in that country. Professor Simola (pp. 465-466), for example, concedes "it is still possible to teach in the traditional way in Finland because teachers believe in their traditional role and pupils accept their traditional position", but he asks "what will happen to teaching and learning in Finnish schools when teachers no longer believe in their traditional mission to be model citizens and transmitters of knowledge, but rather see themselves as facilitators, tutors and mentors. What will happen to teaching and learning in Finnish schools when the pupils no longer accept their position as pupils, but rather 'climb the walls', as one urban primary-school principal put it?"

\section{Conclusion}

India's educational system, like that of many countries, has evolved into a twotier system of schooling. Most Indian children are trapped in government schools of low quality. Those who can afford it pay full fees to place their children in private schools, and their numbers are increasing every year. There are two ways out of this inequitable and inefficient impasse, and they are at opposite ends of the school choice continuum. One possibility is to move the system closer to that of Finland, by prohibiting all independent schools. The second possibility is to move to a system like that of Sweden, with government paying the same grant per pupil to private and government schools.

India already has one part of the Finnish system in place: public school teachers enjoy nearly complete freedom and autonomy. What they lack is the training and professional ethics of Finnish teachers. The Finnish system is "trust based" without external exams or monitoring. This is a system that is difficult to replicate. As Sahlberg (2007, p. 157) explains, "The culture of trust can only flourish in an environment that is built upon good governance and close-to-zero corruption. .... Trusting schools and teachers [in Finland] is therefore a natural consequence of a generally well-functioning civil society and high social capital. Honesty and trust ... are often seen as among the most basic values and the building blocks of Finnish society." These demands would seem to rule out consideration of the Finnish model, certainly for India, and perhaps for any country other than present-day Finland.

The second possibility—the Swedish model-is a viable option and has the added advantage that it respects human rights. A major problem in India is the total lack of accountability of public school teachers. Expanding school choice to everyone-beyond the circle of parents with sufficient income to pay private fees-the government in effect would be employing millions of parents as performance monitors. If a school fails to satisfy expectations, at the end of the school year parents will 'vote with their feet', and the money government spends on education will follow the child.

Not all details of the Swedish system are likely to be implemented in India. Because of wide disparities in income and wealth, it will no doubt be necessary to allow independent, fee-charging schools to continue operation. But no public money should go to such schools. Recognized private schools 
that choose to receive public money should not be allowed to charge top up fees. In exchange, these publicly-financed private schools would receive the same grant per pupil as government schools receive in the same community. It is true that private schools currently operate with much lower expenses than public schools, but there is no reason to discriminate against them in funding. Greater income will allow them to upgrade facilities and increase staff and salaries. If the Swedish experience is any guide, the quality of government schools will increase as well.

\section{References}

Ahlin, Åsa (2003). "Does school competition matter? Effects of a large-scale school choice reform on student performance", Working Paper 2003:2, Department of Economics, Uppsala University, January.

Anonymous (2008). “The Swedish model”, The Economist, 12 June 2008.

Aristotle (1905 [350 BCE]). Politics (translated by Benjamin Jowett, Clarendon Press, Oxford, UK).

Barry, Brian (2001). Culture and equality (Polity, Cambridge, UK).

Björklund, Anders, Melissa A. Clark, Per-Anders Edin, Peter Fredriksson, and Alan Krueger (2005). The Market Comes to Education in Sweden: An Evaluation of Sweden's Surprising School Reforms (Russell Sage Foundation, New York).

Böhlmark, Anders and Mikael Lindahl (2007). "The impact of school choice on pupil achievement, segregation and costs: Swedish evidence", IZA Discussion Paper No. 2786, May.

Glass, Gene V., editor (1994). "School choice: a discussion with Herbert Gintis", Education Policy Analysis Archives 2:6 (20 February). Available at http://olam.ed.asu.edu/epaa/v2n6.html

Drèze, Jean and Amartya Sen (1995). India: Economic Development and Social Opportunity (Oxford University Press, New Delhi, India), especially chapter 6, "Basic education as a political issue", pp. 109-139.

Dwyer, James G. (1998). Religious Schools v. Children's Rights (Cornell University Press, Ithaca, NY).

Fraser Insitute (1999). “The case for school choice: Sweden”, Critical Issues Bulletin. Accessed 6 July 2008 at http://oldfraser.lexi.net/publications/critical issues/1999/school cho ice/

Gamerman, Ellen (2008). “What makes Finnish kids so smart?”, Wall Street Journal, 29 February. 
Gintis, Herbert (1995). “The political economy of school choice”, Teachers College Record 96:3 (Spring), pp. 1-20.

Gradstein, Mark and Moshe Justman (2002). "Education, social cohesion, and economic growth”, American Economic Review 92:4 (September), pp. 1192-1204.

Hawley, Willis D. (1995). "The false premises and false promises of the movement to privatise public education", Teachers College Record 96:4 (Summer), pp. 735-742.

Hirschman, Albert O. (1970). Exit, Voice and Loyalty: Responses to Decline in Firms, Organisations and States (Harvard University Press, Cambridge, MA).

Hoxby, Caroline (2006). School Choice: Three Essential Elements and Several Policy Options (Astra Print, Wellington, New Zealand).

Kingdon, Geeta Gandhi (2007). "The progress of school education in India”, Oxford Review of Economic Policy 23:2, pp. 168-195.

Kremer, Michael and Andrei Sarychev (2000). "Why do governments operate schools?” unpublished paper, Harvard University (October).

Kremer, Michael, Nazmul Chaudhury, F. Halsey Rogers, Karthik Muralidharan and Jeffrey Hammer (2005). "Teacher absence in India: a snapshot", Journal of the European Economic Association 3:2-3 (April/May), pp. 658-667.

Luther, Martin (1962 [1524]). "To the councilmen of all cities in Germany that they establish and maintain Christian schools", translated by A. Steinhaeuser in vol. 45 of Luther's works (Muhlenberg Press, Philadelphia, PA), pp. 347-378.

Macedo, Stephen (2000). Diversity and Distrust: Civic Education in a Multicultural Democracy (Harvard University Press, Cambridge, MA).

Marx, Karl (1875). Critique of the Gotha program (http://www.eserver.org/marx/1875-gotha.critique.txt).

Mill, John Stuart (1909 [1859]). On liberty (Harvard Classics, volume 25, part 2, P.F. Collier \& Son, New York).

OECD (2007). PISA 2006: Science Competencies for Tomorrow's World (OECD, Paris).

Pritchett, Lant (2003) “'When will they ever learn?' Why all governments produce schooling”, BREAD Working Paper No. 031 (June).

Pratham (2006). ASER 2005. Annual Status of Education Report-Rural (Pratham Resource Center, Mumbai, India). 
Pratham (2007). ASER 2006. Annual Status of Education Report-Rural (Pratham Resource Center, Mumbai, India).

Pratham (2008). ASER 2007. Annual Status of Education Report-Rural (Pratham Resource Center, Mumbai, India).

PROBE Team (1999). Public Report on Basic Education in India (Oxford University Press, New Delhi, India).

Reich, Robert B. (2000). “The case for 'progressive' vouchers", The Wall Street Journal (6 September), p. A.26.

Sahlberg, Pasi (2007). "Education policies for raising student learning: the Finnish approach", Journal of Education Policy 22:2 (March), pp. 147171.

Sandström, F. Mikael and Fredrik Bergström (2005). "School vouchers in practice: competition will not hurt you", Journal of Public Economics 89 (February), pp. 351-380.

Sen, Amartya (1997). "Radical needs and moderate reforms", in Indian Development: Selected Regional Perspectives, edited by J. Drèze and A. Sen, (Oxford University Press, New Delhi, India), pp. 1-32.

Shleifer, Andrei (1998). "State versus private ownership", Journal of Economic Perspectives 12:4 (Fall), pp. 133-150.

Simola, Hannu (2005). "The Finnish miracle of PISA: historical and sociological remarks on teaching and teacher education", Comparative Education, 41:4 (November), pp. 455-470.

Willmore, Larry (2004). "Basic education as a human right", Economic Affairs 24:4 (December), pp. 17-23. 